\title{
Eficácia Jurídica das Normas Constitucionais Programáticas
}

\author{
Rafael Dias Toffanello
}

\section{INTRODUÇÃO}

Os estudos acerca das normas constitucionais programáticas remontam o início do século passado. A doutrina clássica iniciou nos Estados Unidos, com Thomas Cooley na obra "Treatise on the constitutional limitations". Esta doutrina foi divulgada no Brasil por Rui Barbosa, Que por sua vez, distinguiu as normas constitucionais na dicotomia auto-executáveis (self-executing provisions) e não auto-executáveis (not-self-executing provisions). As normas auto executáveis são as normas completas, o próprio dispositivo encontra-se armado para sua imediata execução. Por outro lado, as normas não auto-executáveis não se revestem dos meios de ação essenciais ao seu exercício, devendo aguardar Que legislação posterior o faça.

Pontes de Miranda, reiterando a lição de Rui Barbosa, aponta Que as normas nãoauto-executáveis (por ele chamadas de não-bastantes em si), são as que precisam de regulamentação. Sem a criação de novas regras jurídicas que completem ou suplementem, estas normas não podem ser aplicadas. Pontes inclui nas chamadas normas não-bastantes em si as programáticas, sendo aquelas em Que o legislador, constituinte ou não, em vez de editar regras jurídicas de aplicação concreta, apenas traça linhas diretoras, pelas quais os poderes públicos deverão orientar-se.

Revendo a doutrina americana, o italiano Gaetano Azzariti distinguiu entre normas diretivas ou programáticas, as Quais são dirigidas essencialmente ao legislador e normas preceptivas ou obrigatórias, estas últimas subdivididas em normas de aplicabilidade imediata e mediata. Vezio Crisafulli, que estudou profundamente as normas programáticas, distinguiu em normas constitucionais de eficácia plena, aquelas de imediata aplicação, e normas de eficácia limitada, subdividida em normas de legislação e programáticas, destacando-se sua obra titulada "La Costituzione e le sue disposizioni di principio". 
Dentre os doutrinadores de maior destaque na atualidade, Que tratam especificamente sobre o tema da presente monografia, principalmente no Brasil, destaca-se losé Afonso da Silva, em sua obra "Aplicabilidade das Normas Constitucionais". Este doutrinador divide as normas constitucionais em normas de eficácia plena, contida e limitada. Sua segunda classificaçäo, denominada de eficácia contida, única inovação em comparação com a doutrina clássica, é muito criticada. Numa análise mais apurada, verifica-se que José Afonso da Silva apenas dividiu em duas espécies a norma imediatamente executável, pois tanto a norma de eficácia plena como a contida são completas e de aplicação imediata.

Jorge Miranda, sempre pontual, também destaca-se na classificação das normas programáticas, em sua obra "Manual de Direito Constitucional", distinguindo em normas exeqüíveis por si mesmas, normas preceptivas não exęǘveis por si mesmas e normas programáticas.

Diante desta variada distinção em diversas categorias de normas constitucionais, Quanto à eficácia, a presente monografia, em especial, foca no estudo da eficácia jurídica das normas constitucionais programáticas.

Estas normas possuem conteúdo ético-social, representando conquistas da sociedade no decorrer dos anos, no plano da economia, cultura, saúde, ciência, esporte, enfim, são a porta de entrada dos direitos sociais nas constituições. Para obterem eficácia piena necessitam de sua efetivação através de legislação ordinária. Assim, o legislador infraconstitucional efetiva o comando constitucional, determinando o momento e o modo de tornar impositiva a previsão programática, razão pela Qual são normas de eficácia limitada.

Com efeito, a necessidade de efetivação plena do comando programático, através do legislador ordinário, gera uma certa fragilidade do comando constitucional, proporcionando vozes um sua defesa e ataque. Por isso, faz-se necessária a abordagem do conteúdo histórico onde as normas programáticas desenvolveram-se, bem como, a importância da consciência do fim último destas normas, pelo aplicador do direito.

Outra característica abordada é a possibilidade destas normas produzirem direitos subjetivos, já defendido sua impossibilidade por muitos, com o intuito de prevalecer certos interesses em classificar determinado dispositivo com eficácia limitada.

Devido ao papel de extrema importância das normas programáticas no desenvolvimento do país, desenvolveram-se mecanismos jurídicos para criar um ambiente propício para estas normas adquirirem eficácia plena. Estes mecanismos, aqui chamados de eficácia secundária, não visam o fim último da norma constitucional, mas sua proteção. Eln Que pese as divergências acerca da eficácia das normas programáticas, constata-se Que, de uma maneira geral, a eficácia secundária encontra certa semelhança na doutrina. Nestes termos, a programaticidade é uma realidade restrita as normas constitucionais, as Quais, desde o nascimento, apresentam esta característica. 


\section{EVOLUÇÃo dAS NORMAS CONSTITUCIONAIS PROGRAMÁTICAS}

O problema da natureza e eficácia das normas constitucionais está intimamente relacionado com a identificação do teor doutrinário das constituições. Investigando as raízes históricas das constituições, revela-se qual a finalidade suprema que buscam.

Diante da oposição histórica e secular entre a liberdade do indivíduo e o absolutismo do monarca, nasceu a primeira noção do Estado de Direito. Na Revolução Francesa o Estado é armadura de defesa e proteção das liberdades individuais.

A Revolução Francesa, pela sua característica precisa de revolução da burguesia, acarretou a consumação de uma ordem social, onde triunfava o liberalismo.' Ocorreu o rompimento definitivo com a ideologia do passado, firmando a liberdade da burguesia.

A idéia de liberdade no Estado Liberal, inicialmente, está vinculada a idéia de propriedade privada $e$ ao afastamento do Estado da esfera privada, protegendo-se as decisôes individuais. Em outras palavras, há liberdade na medida em Que não há a intervenção do Estado na esfera privada, e em segundo lugar, podemos dizer, segundo o paradigma liberal, Que somos livres, pois somos proprietários. Estes dois aspectos são fundamentais para a compreensão do conceito de liberdade para o pensamento liberal do século XVII e XVIII.

Convém ressaltar a importância da inserção histórica deste pensamento para a sua adequada compreensão. Em primeiro lugar é importante lembrar contra Qual Estado se insurgem os liberais. Não se pode dizer que os liberais são contrários ao Estado Social, ou socialista ou Qualquer outra formulação histórica posterior, justamente pelo fato de Que, o Estado que conheciam e contra o Qual lutavam era o Estado Absoluto.

Quando o Estado foi encarado como o inimigo da liberdade, têm como referência o mencionado Estado Absoluto, Que eliminou toda e vualquer forma de liberdade individual para grande parte da população, e transformou os direitos individuais em direitos de poucos privilegiados. Esta compreensão histórica ajuda a entender porque os liberais afirmam os direitos individuais como direitos negativos, construídos contra o Estado, conquistados face ao Estado. A partir do constitucionalismo liberal o cidadão pode afirmar que é livre para expressar o seu pensamento uma vez que o Estado não censura sua palavra; o cidadão é livre para se locomover uma vez que o Estado não o prende arbitrariamente; o cidadão é livre uma vez que o Estado não invade sua liberdade; a economia é livre uma vez que o Estado não intervém na economia. 
Daí a liberdade tanto em matéria religiosa, como científica, econômica, de livre associação, etc. As forças econômicas necessitavam, para o seu desenvolvimento, a destruição das antigas restrições feudais e mercantilistas, e o Estado Absolutista deveria tornar nova feição. Esta nova roupagem veio com o Estado Liberal, visando proporcionar segurança jurídica e o direito de expansão. ${ }^{2}$

O Estado Liberal sistematiza o individualismo e acima de tudo representa a vitória da burguesia, e logo a vitória dos interesses individuais desta classe, a classe vitoriosa nas revoluções. Quanto ao povo resta o discurso de liberdade, esta reduzida a possibilidade, cada vez mais remota, de se tornarem livres através da aquisição de propriedades, não suas próprias, mas de objetos libertadores.

Porém com a liberdade para o desenvolvimento econômico, ou seja, do capitalismo moderno, acarretou todas as formas de abusos e opressão social, representados por cartéis, trustes, monopólios, lucros ilimitados e extorsivos, exploração do trabalho humano, etc. Diante deste novo panorama social, constatou-se Que a opressão não era mais exercida pelo Estado, mas ao contrário, de certa forças libertadas do seu controle. Estas desconheciam o bem comum, pois o único compromisso era consigo mesmo.

O povo mais sensível à opressão e aos abusos do capitalismo, opõem-se ao Estado Liberal, buscando o bem-estar e ao seu desenvolvimento. Um dos pontos mais significativos desta reação foi a ampliação da democracia pela concessão do direito de voto à massa da população.

Na segunda fase do Estado Liberal, desenvolveu-se a idéia de que a vontade da maioria não pode tudo e Que um governante não pode alegar o apoio da maioria para fazer o Que bem entender. $O$ absolutismo da maioria é tão perverso Quanto o absolutismo de um grupo e a confusão entre opinião pública e democracia sempre muito perigosa

A democracia constitucional liberal, construída no século XIX entende Que a vontade da maioria não pode ignorar os direitos da minoria e os direitos de um só. Os limites a vontade da maioria são impostos pelo núcleo duro, intocável dos direitos fundamentais, protegidos pela Constituiçāo, e Que na época do liberalismo, eram reduzidos apenas aos direitos individuais. A Constituição do Império Brasileiro, 1824 e a primeira republicana, 1891, são constituições liberais eue representam a primeira e segunda fase do Estado Liberal.

2 MEIRELLES TEIXEIRA, losé Horácio. Curso de Direito Constitucional. Rio de Janeiro: Forense, 1991, p. 186. 
As constituiçôes liberais tão-somente estabeleciam a estrutura básica do Estado, seus poderes e competências, assim como, previa relação entre indivíduo e Estado no Que tange unicamente aos direitos civis e políticos.

Estas constituições começaram a entrar em crise a partir do primeiro pós-guerra do século XX, devido a comoçóes ideológicas. Direitos sociais relativos ao trabalho, educação, cultura, previdência, representavam um campo desconhecido do direito constitucional clássico. A sociedade burguesa não tínha um credo político contestado, emergia de um triunfo de idéias sobre a realeza de direito divino e as antigas ordens privilegiadas. ${ }^{3}$

Uma batalha doutrinária iniciou, de um lado, a tese do decadente Estado Liberal e do outro, a do Estado Social, em plena ascensão. A Constituição Alemã de Wiemar representou, revolucionariamente, o moderno constitucionalismo social, representando o auge da crise do constitucionalismo liberal. A referida Constituição, ainda Que através de um texto rude e imperfeito, previa mecanismos voltados para a sociedade e não para o indivíduo. Buscava-se a reconciliação do Estado com a Sociedade, dualismo característico do Estado Liberal do século XIX."

O único valor para o constitucionalismo liberal é a liberdade e para o constitucionalismo social é a igualdade. Porém, a partir de 1946 fala-se em ponderação de valores diversos, sendo o justo uma ponderação de valores, objetivando promover uma situação de ecuilibrio. ${ }^{5}$

Os anseios clamavam por uma ordem social mais justa, por uma distribuição mais eqüitativa da rieueza, pela difusão das coneuistas da ciência e dos confortos da civilização a um número cada vez maior de indivíduos. Originou-se, então, as normas constitucionais programáticas, conferindo a intervenção do Estado em várias esferas da vida humana, tais como a economia, cultura, saúde, relaçoes de trabalho. ${ }^{6}$

\footnotetext{
BONAVIDES, Paulo. Curso de Direito Constitucional. 14 a ed. São Paulo: Malheiros, 2004, p. 231.

BONAVIDES, Paulo. op. cit. p. 233.

5 Segundo MIRANDA, lorge: “Nas Constituiçōes liberais do século XIX, as normas substantivas eram Quase todas normas orgânicas e as normas de fundo circunscreviam-se aos direitos, liberdades e garantias. Dominavam, portanto, as normas perceptivas. Nas Constituiçôes com intenções sociais, de diversas inspiraçōes, do século $\mathrm{XX}$ as normas de fundo, bem como as normas de garantia, dilatam-se muitíssimo a prever direitos sociais e a organização económica. Deparam-se então, em targo número, normas programáticas." Manual de Direito Constitucional. Tomo 11. Coimbra: Coimbra, 1996, p. 245 e 246.

6 Conforme MIRANDA, Pontes: "Nas constituiçöes de 1934, de 1937, de 1946 (aliás na esteira aberta pela Constituição Alemã de 1919) e de 1967, as regras jurídicas de caráter programático apareceram amiúde. É o sinal do tempos. O fracasso do liberalismo econômico, Que esvaziou de fins precissos o Estado e Quase o reduziu a mero assistente das lutas entre os indivíduos, os grupos e as classes, sugeriu a formação de partidos de idéias nítidas e inconfundíveis, Que pudessem obviar, com a sua ação, à ausência nefasta de fins precisos do Estado. Tal direção nova refletiu-se na própria técnica constitucional, e as Constituiçóes contemporâneas receberam a sugestão da necessidade, por todos sentida, de se inserir nos textos constitucionais afguma coisa que dissesse para onde se vai e como se vai." Comentários à Constituição de [967. Tomo ]. São Paulo: RT, 1967, p. 127.
} 
A trégua entre a batalha ideológica veio com a inserção de fórmulas programáticas nos textos das constituições. A programaticidade representou a porta de entrada dos direitos sociais nas Constituições, porém gerou uma outra crise de ordem conceitual da Constituição. Devido à problemática acerca da normatividade das normas programáticas, pairava a dúvida Quanto ao conceito jurídico ou político de Constituição.

Pode-se encontrar facilmente normas programáticas na Constituição da República Federativa do Brasil de 1988, tais como o uso propriedade em seu sentido social, justa distribuição de terras, intervenção do Estado na economia, regulamentação dos serviços públicos, política agrícola, fundiária e de reforma agrária, prestação de serviços de saúde pelo Estado, de educação, cuitura, desporto, ciência e tecnologia.

Percebe-se, desde já, Que as normas programáticas estão sujeitas ao inevitável influxo do desenvolvimento histórico, refletem mais fiełmente o conteúdo profundo dos valores em circulação e mudança na sociedade. Razão pela Qual, seu caráter técnico jurídico, dentre as normas constitucionais, se mostra mais fraco e impreciso.

Os elementos programáticos representam e concretizam o sentido e a finalidade da ação do Estado, correspondendo em nossos dias, aos chamados fins sociais do Estado, direitos e pretensões de sentido social. Que foram absorvidos pelas Constituições modernas, incorporando a moldagem de preceitos constitucionais.

As normas progranáticas representam a feição social das Constituições modernas, a transposição de valores-fins, convicções sociais, políticas e filosóficas para o âmbito constitucional. Fixam finalidades supremas e essências do Estado, refletindo concepções da vida e do mundo, estabelecem um norte a ser observado.

Com efeito, ainda pairam dúvidas Quanto a eficácia e juridicidade das normas programáticas, pois, dentre a normas constitucionais, são as mais frágeis. Esta eficácia tanto pode ser invocada para configurar a natureza política e ideológica do regime, como infelizmente para legitimar a inobservância de algumas determinações constitucionais.

Nestes termos, constata-se que a evolução histórica das Constituiçōes desencadeou na face programática destas, permanecendo, ainda hoje, uma nebulosa fronteira entre a Política e o Direito.

\section{IMPORTÂNCIA DA CONSCIÊNCIA JURÍDICA}

A norma constitucional programática, ao invés de disciplinar diretamente a matéria a Que se refere, transfere ao legislador ordinário a consecução dos seus fins essenciais. Assim, o legislador ordinário, próximo aos reclames da sociedade e ciente de sua real capacidade econômica, política e administrativa para suprir as necessidades sociais, efetiva o comando constitucional, 
Com efeito, verifica-se que a eficácia plena das normas programáticas será conquistada pelo legislador ordinário. Devido ao objeto destas normas serem de cunho ético-social, constituem uma obrigação solene assumida pelo próprio Estado.

Observa-se Que a efetivação destas normas está intimamente relacionada à política, aos futuros programas de governo a serem colocados em prática pelos representantes eleitos democraticamente pelo povo. Ocorre Que, inúmeras vezes Quando a política não atende satisfatoriamente aos problemas sociais, o Poder Judiciário cai em tentação, interferindo em Questões políticas.

Há Que se ter presente que a Constituição da República é um texto fundamentalmente jurídico de conteúdo moral, econômico, político, etc, e não instrumento para exercer um poder arbitrário. Uma verdadeira Carta Magna é o início de uma caminhada de homens livres, e não um conjunto de regras estanques, Que impedem escolhas futuras.

O jusfilósofo e jurista Miguel Reale, ao contribuir para os trabalhos da Assembléia Nacional Constituinte Brasileira de 1987, denominou de "totalitarismo constitucional" a errônea imagem que a Constituição, por ser a lei suprema, pode indicar obrigatoriamente um único caminho, negando a liberdade de escolha política de um povo." Afirma, outrossin, Que uma Constituição não é, nem pode ser, a pré-moldagem da sociedade civil, mas sim o enunciado de modelos jurídicos abertos capazes de propiciar-lhe meios e modos para superar inevitáveis conflitos econômicos, políticos ou culturais através do livre jogo dos interesses e das idéias, conforme as opçóes soberanas do eleitorado. ${ }^{8}$

Assim, a Constituição não relaciona um rol de soluções, por outro lado, é a garantia Que, com base na experiência social, estas sejam livremente alcançadas. É impossível um comando normativo constitucional antecipar entendimentos e negociações a serem futuramente concluídos pelos indivíduos interessados."

No mesmo passo. Geraldo Ataliba afirma que são características da República a eletividade, a periodicidade e a responsabilidade, sendo esta última o penhor da idoneidade da representação popular. O mencionado autor refere Que no intenso diálogo político Que precedeu à reunião da convenção constituinte, o povo fixou os grandes rumos, diretrizes de governo Que Quis ver concretizadas. ${ }^{10}$

7 REALE, Miguel, Liberdade e Democracia. São Paulo: Saraiva, 1987, p.17.

\& REALE, Miguel. op.cit. p.I7.

- Conforme posiçäo de FERREIRA FILHO, Manoel Gonçalves: "[...] cunpre năo esquecer que a Constituinte é um meio. Ela serve para estabelecer una Constituição. Mas năo basta reunir uma Constituinte para Que apareçam claras e exeeüiveis as soluções de todos os problemas nacionais. Nem esta solução se encontra na copia dos textos estrangeiros de maior êxito ou prestígio. As instituições não 'pegam' e não dão bons frutos Quando estabelecidas sem levar en conta os fatores históricos, políticos, econônicos, estritamente sociais, Que marcam cada povo." O Poder Constituinte. 2a ed. São Paulo: Saraiva, 1985, p.158.

${ }^{10}$ ATALIBA, Geraldo. República e Constituição. $2^{\text {a }}$ ed. Săo Paulo: Malheiros, 2001 , p. 14. 
Este debate, entre o povo e os políticos, serve para amadurecer e identificar as prioridades a serem atendidas por programas políticos, escolhidos por eleição popular. Os representantes eleitos Que se desviam dos termos do mandato devem receber censura e desaprovação do povo, mediante sua não reeleição. Daí a importância da periodicidade, pois serve como estímulo para o representante ser fiel aos desejos representados.

Estes mecanismos servem de proteção à democracia, preservando os rumos, diretrizes e norte determinado pelo povo, pois representam seus desejos, angústias e preocupações. Sua eficácia fica vinculada e assegurada pelas normas que os representantes eleitos ficam obrigados a adotar.

Consiste $\mathrm{cm}$ traição ao povo, em outras palavras, uma verdadeira negação da democracia, consagrar apenas retoricamente os princípios popularmente fixados e. ulteriormente, estabelecer regras Que os esvaziem ou contravenham.

A natureza das relaçōes Que as normas constitucionais programáticas disciplinam são de cunho eminentemente político e social, razão pela Qual, estão sujeitas a um influxo político considerável. Os governos, no exercício de suas atribuições, não podem ignorar estes comandos constitucionais. " Estas normas fixam parâmetros dentro dos Quais o legislador há de definir um corpo coerente de regras obrigatórias, estabelecendo um conteúdo prescritivo, o Que falta aos programas. Consoante a doutrina de Manoel Gonçalves Ferreira Filho, cabe ao legislador a escolha do momento e o modo de tornar juridicamente impositiva a previsão programática, razão pela Qual, o descumprimento não desafia a inconstitucionalidade por omissão. ${ }^{12}$

Seria um erro fatal desmembrar as normas programáticas de seu terreno político e ideológico, pois é o que confere vida a norma, torna o Direito dinâmico e não estanque. Assim o legislador constituinte, ciente Que seu poder não é ilimitado, busca inspiração no momento histórico de seu povo, bem como, numa concepção universal do mundo e da vida, conforme já tratado no Capítulo I deste trabalho. ${ }^{13}$

"BONAVIDES, Paulo. Curso de Direito Constitucional. $14^{a}$ ed. São Paulo: Maheiros, 2004, p.461.

12 Assim se posiciona FERREIRA FiLHO, Manoel Gonçalves: "Disso decorre que, tendo a discriçăo quanto ao momento $\mathrm{e}$ o modo de tornar juridicamente impositiva a promessa (progranática), o legislador não descumpre a Constituição porque retarda, se omite, na regulamentação, de preceilo năo auto-executável da Lel Suprema. Ao contrário, essa omissão se coaduna com o cumprimento da Constituição porque esta - reiterese - deixou ao legislador a escolla do momento (bem como do modo) de execução de norma programática." Estado de Direito e Constituição. Săo Paulo: Saraiva, 1988, p.101.

13 Conforme FERREIRA FILHO, Manoel Gonçaves: "Dentro de uma perspectiva positivista, o Poder Constituinte é juridicamente ilimitado, por uma razão óbvia, porque, para a doutrina positivista, não há dircito antes da manifestação do Poder Constituinte. [...] dentro de uma perspectiva jus naturalista, dentro de eualquer das doutrinas do direito natural, o Poder Constituinte originário é limitado. É limitado pelo direito naturał." O Poder Constituinte. $2^{a}$ ed. São Paulo: Saraiva, 1985, p.70 e 71. 
Conforme posição de Miguel Reale:

"Nenhuma ofensa é maior a esta do Que a pretensão que possa ter um pequeno grupo de homens de decidir de tudo e sobre zudo, substituindo-se ao povo Que deles espera a elaboração de regras Que assegurem a todos a liberdade como participaçáo à causa comum do bem-estar e do progresso". (REALE, 1987, p. 17)

Na democracia social a liberdade Que se Quer garantir e realizar não é, por conseguinte, apenas a do cidadão genericamente considerado, mas a do homem situado diante de suas circunstâncias individuais, sociais e históricas. Cabe ao legislativo, cujo poder foi outorgado pelo povo, traduzir a vontade política da população, pois numa democracia é o poder habilitado para tanto.

A clássica liçăo de Montesquieu acerca da separação de poderes, traduz a necessidade de divisăo do trabalho e sobretudo na limitação do poder. Os poderes representativos são constituídos por indivíduos investidos do poder de Querer pela nação, fazendo prevalecer em Qualquer deliberação a vontade nacional. ${ }^{14}$

A organização de poderes, acarreta sua limitação, assim como, o mecanismo de freios e contrapesos. A Constituição ao dividir o poder estatal entre órgãos diferentes e independentes, impede que um possa tudo. Com esta limitação promove a garantia de liberdade para seu povo. Conforme já mencionado, uma Constituição é o início de uma caminhada de homens livres, para fazerem opçōes futuras.

O político é o global, é tudo aquilo Que assume relevância para toda uma sociedade ou um conjunto de sociedades, em determinado tempo e lugar. A essência do político encontra-se sobretudo na dialética do grupo humano e do poder, onde o grupo confere enquadramento ao poder, modela os homens que o exercem, reconhece-lhes legitimidade. O poder político (a que se exige do que a Qualquer outro poder) gera um processo próprio de agir e afirmar-se em graus variáveis, sendo que no Estado chegam à autonomia. Contudo, porque o poder está em relação com fins pressupõe pessoas que os partithem, ele é o poder numa comunidade, pressupõe obediência e é obediência transformada. ${ }^{15}$

${ }^{14}$ Segundo MEIRELLES TEIXEIRA, losé Horácio: "[...] a técnica de divisäo dos poderes faz parte, evidentemente, da organização e da estrutura do Estado, das Quais aparece mesmo como elemento importantíssimo. Mas a divisão dos poderes constitui também uma técnica da organização da liberdade, conno uma garantia contra o despotismo, e foi este, justamente, o seu aspecto em que especialmente insistiu Montesquieu, e que mais impressionou os constitucionalistas da Revoluçăa Francesa e do fiberalismo clássico." Cułso de Direito Constitucional. Rio de Janeiro: Forense, 1991 , p.189.

is MIRANDA, Jorge. Teoria do Estado e da Constituição. Rio de laneiro:Forense, 2002, p.168 e 169. 
Frente a estas considerações, importa a esclarecedora lição de Manoel Gonçalves Ferreira Filho, com reflexos diretos na importância da limitação dos poderes, senão vejamos:

"[...] deve-se ter presente Que as normas programáticas reclamam o mais das vezes uma mobilização de recursos e meios, financeiros ou não, Que a mera decisão não poderá lograr. Imagine-se uma sentença Que reconheça o direito à moradia onde não houver habitação disponível. Qual seria o seu efeito prático? E uma decisão judicial inócua não é sem conseQüências: tem uma pelo menos, a de desprestigiar o Judiciário, enfraquecendo-o [...] Ora, é ele o principal guardião da liberdade; sua fraqueza, sua desmoralização abrem sempre porta para o abuso". (FERREIRA FILHO, 1988, p. 102)

Percebe-se Que as normas constitucionais programáticas representam fielmente uma pré-cognição Que podemos denominar de consciência jurídica. É a percepção da matéria Que deve figurar no estatuto político fundamental de um País. Devendo prevalecer na Constituição normas Que preservem a ampla liberdade de escolha do eleitorado, conforme futuros programas de governo a serem implantados. ${ }^{16}$

Percebe-se a limitação do legislador constituinte ao tratar de matéria de cunho social, conferindo para o povo, através de seus representantes, liberdade para estabelecer Qual a solução mais apropriada. Esta escotha gravita no campo político, onde a diversidade de ideologias apontam cada una para uma direção. Logicamente esta escolha deve ser tomada pelos Poderes Legislativo e Executivo, legitimados pelo processo democrático para tal fim.

Esta percepção de que para existir una democracia há Que prevalecer uma noção de limitação do poder é de surna importância para não ocorrer o conflito entre política e direito. Como e Quando será concretizada a norma constitucional programática através de serviços públicos nẩo pode ser objeto de decisão judicial. Além de afrontar o texto Constitucional estar-se-ia desequilibrando a balança entre os poderes.

A política cuida da pessoa como ser social, o Que requer a instituição de regras de convívio para Que se possa garantir a realização plena de cada indivíduo. Cumpre à política o estabelecimento de um clima de convívio, onde os membros da sociedade possam desenvolver, com liberdade, os potenciais da personalidade. Por sua vez, a ética visa indicar, ao ser racional e livre, onde estão os fins últimos do humano, ou seja, a felicidade, assim como, as vias para alcançá-la. Num Estado Democrático o direito tem por finalidade estabelecer uma ponte entre a política e a ética, sem pretensão de substituição. ${ }^{17}$

16. REALE, Miguel. Liberdade e Democracia. São Paulo: Saraiva, 1987, p.19.

17 SOUZA IUNIOR, Cezar Saldanha. A Supremacia do Difeito no Estado Democrático e seus modelos básicos. Porto Alegre: 2002, p. 179. 
A autonomia ética e política melhor se aplica no ideal contemporâneo de organização institucional de Estado que é a democracia, pois envolve todo um processo de representação e participação da população na esfera do poder. A supremacia do direito (Law's Empire) é um instrumento de garantia da política e da vida social, uma verdadeira harmonização, evitando distorções. O direito faz uma ligação entre o ético e o político, respeitando a autonomia legítima destas essências, sem pretensão de substituição.

Direitos sociais referentes à saúde, educação, lazer, desporto, moradia, etc., conferidos pelo |udiciário a um cidadão, e que não é oferecido para a coletividade, está fadado a prejudicar toda a nação, considerando Que numa decisão judicial é impossível cuidar dos recursos orçamentários a serem utilizados no custeio do serviço.

Disto decorre uma situação de instabilidade entre os Poderes, onde o ludiciário interfere tanto como legislador ao determinar Qual o serviço Que deverá ser prestado, como governante, ao determinar Que o erário suporte todos os efeitos de sua decisão. A administração financeira do Estado, bem como a definição de estratégias e políticas para a melhor aplicação dos recursos públicos a fim de atender às necessidades da população, por óbvio, fogem da alçada do Poder Judiciário.

\section{NORMAS CONSTITUCIONAIS PROGRAMÁTICAS E DIREITOS SUBJETIVOS}

Para uma methor compreensão da eficácia das normas programáticas, deve-se, também, tecer algumas considerações no sentido da possibilidade destas normas produzirem situações jurídicas subjetivas. Salienta-se que é matéria muito controvertida na doutrina, onde militam fortes razões para ambas correntes. ${ }^{18}$

Modernamente concluiu-se que nem todo interesse juridicamente protegido se inclui na categoria dos direitos subjetivos. A partir daí nasce a noção de situações jurídicas subjetivas, não como substituição ao conceito de direito subjetivo, mas visando abranger todos interesses relevantes para o Direito. ${ }^{19}$

${ }^{18}$ Os estudo das situaçôes jurídicas deve partir da consideração dos interesses de sua proteção pela ordem juridica. Segundo Rudoff Von thering o escopo do direito é tutelar os bens ou interesses. Concebe o direito subjetivo como interesse juridicamente protegido, não como mero interesse psicológico, mas conforme certos valores e interesses. Por sua vez, interesse expressa o valor do bem em relação ao sujeito e seus lins enquanto valor dá a medida da utilidade deste bem. Esta definição de direito subjetivo opõe-se à delinição do direito subjetivo como poder da vontade. Georg fellinek concilia as duas posiçóes no seu conceito de direito subjetivo, afirmando que é o poder de Querer que tem o homem, reconhecido e protegido pela ordem Juridica, eneuanto dirigido a um bem ou interesse.

19 Conforme DA SILVA, José Afonso: "Quando o direito não protege certos interesses, não os tem como valor digno de sua tutela, dizem-se interesses juridicamente irrelevantes. Aqueles interesses que o Direito tem como valor digno de tutela săo os juridicamente relevantes. Nesta classe, distinguem-se os simples interesses, as expectativas de direito, os interesses legítimos, os direitos condicionados e dos direitos subjetivos. As situações jurídicas subjetivas envolvem a consideraçäo desses interesses juridicamente relevantes, e sua proteção é tanto mais intensa Quanto mais eficazes forem as normas que as têm como objeto." Aplicabilidade das Normas Constitucionais. São Paulo: Malheiros, 1998, p.169. 
Esta situação jurídica subjetiva pode ser classificada em negativa ou positiva, sendo Que esta consiste na possibilidade, reconhecida pela norma jurídica, de o indivíduo ou entidade realizar certo interesse por ato próprio ou exigindo ação ou omissão de terceiros. Por sua vez a situação jurídica subjetiva negativa consiste no dever ou na obrigação de submeter-se o indivíduo às exigências de realizar uma prestação, ação ou abstenção.

As normas programáticas, por óbvio, protegem certos interesses, porém, neste caso particular, os sujeitos da norma são aQueles oue, mesmo indiretamente, se encontram em condição de tirar vantagem de sua aplicação e observância. Ao dever do Estado consiste em realizar e proteger certos interesses descritos nas normas em comento. ${ }^{20}$

Conforme Meirefles Teixeira, é possível identificar normas constitucionais programáticas destinadas à proteção do interesse geral, e que por via reflexa protege um direito individual e vice-versa. Toma como exemplo a norma contida no artigo $215 \mathrm{da} \mathrm{CF} / 88$ a Qual prevê Que o Estado garantirá a todos o pleno exercício dos direitos culturais ${ }^{21}$.

Os chamados direitos culturais abrangem a formação educacional de toda a população, expressōes criadoras da pessoa e das projeções do espírito humano materializadas em suportes expressivos, portadores de referências à identidade, à ação, à memória dos diferentes grupos formadores da sociedade brasileira. ${ }^{22}$

Neste caso, o interesse dos beneficiários indiretos das normas é juridicamente relevante, como interesse constitucionalmente protegido. Porém, tal situação não configura um direito subjetivo, pois inexiste um interesse individual de exigir o cumprimento. A observância da norma por parte dos órgãos estatais é discricionária, ou seja, possui poder de escolha Quanto a oportunidade, meios e modo de agir. Assim, a proteção ao interesse individual é exercida apenas indiretamente, através de normas Que conferem poder discricionário ao Estado. ${ }^{23}$

Por sua vez, há normas programáticas Que visam proteger diretamente certos interesses individuais, e apenas indiretamente o interesse coletivo. ${ }^{24}$ Pode-se exemplificar com a norma contida no artigo 170 , inciso VIII da CF/88, a Qual prevê como princípio da ordem econômica a busca do pleno emprego. Pleno emprego significa propiciar trabalho a todos Quantos estejam em condições de exercer uma atividade produtiva. Este dispositivo se

20 Conforme MEIRELLES TEIXEIRA, José Horácio: "É fora de dúvida, portanto, Que as normas de eficácia limitada, especialmente as programáticas, destinam-se a tornar obrigatórios certos comportamentos estatais, a realizar ou proteger certos interesses, ora diretamente, ficando o interesse geral, coletivo, num segundo plano; ora indiretamente, porque em primeiro plano se acha o interesse coletivo, e o interesse individual scrá protegido, então, apenas reflexamente, como decorrência da conseqüência da promoçăo do interesse geral." Curso de Direito Constitucional. Rio de laneiro: Forense, 1991, p.352.

21 MFIRELLES TEIXEIRA, José Horácio. Curso de Direito Constatucional. Rjo de laneiro: Forense, 1991, p. 354.

27 DA SILVA, losé Afonso. Curso de Direito Constitucional Positivo. São Paulo: Malheiros, 1999, p.809.

${ }^{23}$ MEIRELLES TEIXEIRA, losé Horácio. op.cit. p. 354 e 355.

24 MEIRELLES TEIXEIRA, losé Horácio. op.cit. p.355. 
harmoniza com a previsão Que a ordem econômica se funda na valorização do trabalho humano, tendo por fim assegurar a todos existência digna. Assim, não pretende-se apenas Que a economia absorva a força de trabalho disponível, como consumo absorve mercadorias. A base ideológica presente é de que o trabalho seja a base do sistema econômico, receba o tratamento de principal fator de produção. ${ }^{25}$

Verifica-se eue a nomna contida no referido artigo 170 , inciso VIII da CF/88, destinase aos indivíduos desempregados, porém não confere aos destinatários a possibilidade de exigir trabalho, nem do Estado, nem de particulares, somente com base na Constituição. ${ }^{26}$

Divergindo de Meirelles Teixeira ${ }^{27}$, losé Afonso da Silva sustenta que as normas constitucionais programáticas do artigo 170, inciso III (função social da propriedade), art. 215 (o Estado garantirá a todos direito à cultura) e outras semelhantes, conferem situações subjetivas positivas. Para o referido autor, estes incisos são passíveis de oferecerem ao particular a possibilidade invocá-los visando embasar dissídio Que o favoreça. ${ }^{28}$ Por outro lado, os referidos autores concordam Que as normas constitucionais programáticas contidas nos artigos 170, incisos VII (redução das desigualdades regionais e sociais e VIII (busca do pleno emprego), protegem interesse geral, não conferindo aos beneficiários o poder de exigir sua satisfação. ${ }^{29}$

Segundo lorge Miranda:

"As normas programáticas são de aplicação diferida, e não de aplicação ou execução imediata; mais do Que comandos-regras explicitam comandosvalores; conferem elasticidade ao ordenamento constitucional; têm como destinatário primacial - embora não único - o legislador, a cuja opção fica a ponderação do tempo e dos meios em Que vêm a ser revestidas de plena eficácia (e nisso consiste a discricionariedade); não consentem Que os cidadãos ou Quaisquer cidadãos as invoeuem já (ou imediatamente após a entrada em

${ }^{25}$ DA SIIVA, José Afonso. op.cit, p.771.

${ }^{26}$ MEIRELLES TEIXEIRA, José Horácio. op.cit. p.356.

27 A posição de BARROSO, Luís Roberto é a mesma de Meirelles Teixeira, senão vejamos: "As normas programáticas veiculam princípios, desde logo observáveis, ou traçam fins sociais a serem alcançados pela ação futura dos poderes públicos. Por sua natureza, não geram para os jurisdicionados a possibilidade de exigirem comportamentos comissivos, mas investem-nos na faculdade de demandar dos órgãos estatais Que se abstenham de Quaisquer atos Que contravenham as diretrizes traçadas. Vale dizer: näo geram direitos subjetivos na sua versão positiva, mas geram-nos em sua feição negativa. São dessa categoria as regras que preconizam a função social da propriedade (art. 170 , lill), a redução das desigualdade regionais e sociais (art. 170. Vil), o apoio à cultura (art. 215), o fomento às práticas desportivas (art. 217), o incentivo à pesquisa (art. 218 ) etc." Interpretação e Aplicação da Constituição. São Paulo: Afiliada, 1996, p. 228.

28 Para DA SILVA, José Afonso: "O princípio da função da propriedade, por exemplo, pode ser invocado contra o abuso desse direito, em certas circunstâncias, em prol de inquilinos contra o senhorio, e especialmente impor atuaçōes posittivas ou abstençóes ao proprietário, no interesse da coletividade." Aplicabilidade das Normas Constitucionais. Sâo Paulo: Malheiros, 1998, p. 177.

29 DA SILVA, losé Afonso. op.cit. p.176. 
vigor da Constituição), pedindo aos tribunais só por sí, pelo que pode haver Quem afirme que os direitos que delas constam, maxime os direitos sociais, têm mais natureza de expectativas que de verdadeiros direitos subjetivos; aparacem, muitas vezes, acompanhadas de conceitos indeterminados ou parcialmente indeterminados." (MIRANDA, I., 1996, p. 244 e 245)

Conceituando o chamado direito público subjetivo, Pontes de Miranda assim leciona:

Para que exista o direito público subjetivo, é preciso que alguém, pessoa fisica ou jurídica (nacionais, apátrides, estrangeiros, Estados-membros, Comunas ou Municípios, etc.), possa, por ato seu, restringir a atividade legislativa ou administrativa do Estado, ou obțer a restrição, no terreno do direito público. [...] Durante a elaboração da Constituição de 1934, citaramse textos nossos, referentes a certos direitos, Que entendemos sejam a pedra angular de Constituição duradoura, concebidos como direitos públicos subjetivos; mas é de lamentar que se não haja atendido para à diferença, jurídica e politicamente, assaz relevante - entre regras jurídicas constitucionais que, Quando muito, conferem posições de direito objetivo e regras jurídicas que contêm direitos públicos subjetivos. A existência de direito à subsistência, de direito ao trabalho, de direito à educação, de direito à assistência e de direito ao ideal, em textos, sem se lhes dar o caráter de direitos públicos subjetivos, e a não-existência de direitos públicos subjetivos àQuelas prestações do Estado, provam Que a construção Que propusemos é nova. Tais direitos seriam novos e toda a Questão social gira em torno deles. A solução soviética, violenta, estabeleceu o fim revolucionário Que pudesse garant:los em sistema de reflexos do direito objetivo. Para a solução menos violenta pareceu-nos (e continuamos convictos disso) Que só a subjetivação pode satisfazer. A declaração deles, no Estado sem o fim revolucionário e como simples reflexo do direito objetivo, constitui letra morta, enfeite doutrinal, sem Qualouer realidade palpável, e motivo para inexaurível demagogia." (MIRANDA, P., 1967, p. 133 e 134, grifo do autor)

Pode-se dizer que de uma maneira geral, não pacífica, as normas programáticas geram situações subjetivas negativas. Estas constituem-se no dever do legislador exercer seu poder dentro de certos limites, de certo modo, Que não contrarie a norma programática. Da mesma forma, a atividade discricionária da Administração também está obrigada a desenvolver-se conforme os fins e objetivos previstos na norma. Há uma verdadeira proibição de Qualquer atividade em contrário às próprias normas, não apenas da atividade legislativa mas também de toda e Qualquer atividade estatal.

Verifica-se que a lei ou atos normativos da Administração Que contrariem disposições programáticas geram direitos subjetivos negativos para o indivíduo. Assim, fixados pela norma programática determinados princípios, diretrizes, orientaçôes ou limitações ao 
legislador e demais órgãos estatais, desafiados por lei ou ato normativo contrário, nasce o direito ao controle de constitucionalidade destes dispositivos. ${ }^{30}$

Assim, o cidadão pode suscitar a exceção de inconstitucionalidade nos confrontos de uma lei, por exemplo, em matéria econômico-social, Que afronte norma da própria Constituição. Sempre que uma lei ordinária ou ato normativo da Administração imponham obrigações, estabeleçam ônus, neguem benefícios, estabeleçam limitações à atividade individual, contrariamente à princípios programáticos, nasce a possibilidade de suscitar a declaração de inconstitucionalidade. Nestes termos, o cidadão poderá exigir da Administração Pública ou particular que se abstenha do ato, atividade ou exigência inconstitucional. ${ }^{31}$

\section{EFICÁCIA JURÍDICA DAS NORMAS CONSTITUCIONAIS PROGRAMÁTICAS}

As normas constitucionais programáticas não regulam diretamente a matéria Que se referem, mas regulam propriamente a atividade estatal concernente a ditas matérias. Tem por objeto imediato os comportamentos estatais e só mediatamente, ou em segundo grau, aQuelas determinadas matérias. Em rigor, a norma programática vincula comportamentos públicos futuros, estabelecendo premissas destinadas a vincular o desdobramento da ação legislativa dos órgãos estatais, assim como, regulamentar certa ordem de relações. É sem dúvida a categoria de normas constitucionais onde paira maior dúvida Quanto a sua eficácia.

Previamente faz-se necessário definir, ainda Que brevemente, alguns conceitos de suma importância no campo da eficácia das normas constitucionais. Basicamente há que ser feita distinção entre vigência, aplicabilidade e eficácia. Vigência é a Qualidade da norma Que a faz existir juridicamente e a torna de observância obrigatória, ou seja, caracteriza o direito Que rege, aQui e agora, as relações sociais. A vigência é condição de efetivação da eficácia, ainda Que, tratando de norma constitucional, dependa de outras normas infra-constitucionais para ser eficaz. ${ }^{32}$

Aplicabilidade exprime uma possibilidade de atuação concreta da norma, mediante o enquadrar um caso concreto na norma jurídica adequada. Submete às prescrições abstratas da leỉ uma relação da vida real, através do dispositivo adaptável ao fato determinado.

20 MEIRELles TeIXEira, losé Horácio. Curso de Direito Constitucional. Rio de Janeiro: Forense, 1991. p.357.

${ }^{31}$ Conforme DA SILVA, José Alonso: "Se não se tern direito subjetivo no seu aspecto positivo, como poder de exigir uma prestação fundada numa norma constitucional programática, surge ele, porém, em seu aspecto negativo, como possibilidade de exigir que o Poder Público näo pratique atos que a contravenham." Aplicabilidade das Normas Constitucionais. São Paulo: Malheiros, 1998, p. 177.

${ }^{32}$ DA SILVA, losé Afonso. Aplicabilidade das Normas Constitucionais. $3^{a}$ ed. São Paulo: Matheiros, 1998, p. 52 . 
Por sua vez, eficácia é a capacidade de atingir objetivos previamente fixados como metas. Tratando-se de normas jurídicas, a eficácia consiste na capacidade de atingir os objetivos nela traduzidos, Que vêm a ser, em última análise, realizar os ditames jurídicos objetivados pelo legislador. Nestes termos, a eficácia da norma designa a Qualidade de produzir, em maior ou menor grau, efeitos jurídicos, ao regular, desde logo, as situações, relaçōes e comportamentos de Que cogita.

Partindo da premissa que todas as normas constitucionais possuem eficácia, ainda que pequena, José Afonso da Silva classificou as normas constitucionais em três categorias, chamadas de normas constitucionais de eficácia plena, eficácia contida e eficácia limitada ou reduzida.

Normas constitucionais de eficácia plena são aquelas que produzem todos os seus efeitos, desde sua entrada em vigor, incidindo direta, imediatamente e integralmente sobre a matéria Que thes constitui objeto. Na doutrina americana são denominadas self-executing ou self-enforcing, segundo Rui Barbosa auto aplicáveis e Pontes de Miranda chamou de bastantes em si.

São aquelas que produzem, ou tem a possibilidade de produzir, todos os efeitos essenciais, relativamente aos interesses, comportamentos e situaçōes Que o legislador constituinte, direta e imediatamente, Quis regular.

Distanciando-se da doutrina clássica, José Afonso da Silva concebeu a categoria das normas constitucionais de eficácia contida. Justifica que tal categoria se faz necessária em razão das particularidades de certas normas, similares as de eficácia plena e limitada..$^{33}$ Sua aplicabilidade independe de legislação futura, porém, depende dos limites a serem definidos pelo legislador ordinário, daí o termo "contida". Inexistindo legislação Que restrinja a norma de eficácia contida sua eficácia será plena. Os pontos comuns à crítica a esta categoria concentram-se basicamente Que trata-se na verdade de eficácia plena e o adjetivo deveria ser restringível.

A última categoria, das normas constitucionais de eficácia limitada, é bifurcada em normas de princípio institutivo ou organizativo e princípio programático. Na doutrina americana denomina-se non-self-executing ou non-self-enforcing, náo auto aplicáveis para Rui Barbosa e não bastantes em si para Pontes de Miranda.

Diz-se eficácia limitada poreue não basta a vigência da norma para produzir todos os seus efeitos, sua aplicabilidade é indireta, mediata e reduzida. Nestes termos, cabe ao legislador ordinário desenvolver a eficácia destas normas.

33 Segundo DA SILVA, José Afonso: "As normas de eficácia contida, portanto, são aquelas em que o legislador constituinte regulou suficientemente os interesses relativos a determinada matéria, mas deixou margem á atuação restritiva por parte da competência discricionária do Poder Público, nos termos Que a lei estabelecer ou nos termos de conceitos gerais nelas enunciados." Aplicabilidade das Normas Constitucionais. 3 ed. São Paulo: Malheiros, 1998, p. 116. 
Entende por norma de princípio institutivo ou organizativo "aQuelas através das Quais o legislador constituinte traça esquemas gerais de estruturação e atribuições de órgâos, entidades ou institutos, para Que o legislador ordinário os estruture em definitivo, mediante lei." 34

Por último, a normas constitucionais de eficácia programática são aquelas em Que o poder constituinte não regula direta e imediatamente determinados interesses Que são fins sociais do Estado, por sua vez, são princípios a serem observados para atingir estes fins. $O$ legislador ordinário deve buscar a efetivação das normas programáticas segundo os ditames postos na Constituição, porém à luz da realidade sócio-econômica onde encontra-se inserido.

Na concepção de Meirelles Teixeira, a norma programática não disciplina diretamente a matéria a Que se refere, para a imediata obtenção de seus fins essenciais, mas o legislador constituinte preferiu regular apenas os comportamentos estatais destinados à obtenção final daqueles efeitos. Adverte que a norma está apta a produzir de imediato eficácia somente Quanto aos seus fins não primordiais, mas secundários. Quantos aos efeitos essenciais, cabe à sociedade, através de seus representantes eleitos democraticamente, legislar ordinariamente produzindo eficácia aos comandos programáticos previstos na Constituiçãa ${ }^{35}$

Segundo Pontes de Miranda as normas programáticas são algo Que era político, partidário, programático e entrou no sistema jurídico, cerceando-se, com isso, a atividade dos legisladores futuros, Que no assunto programado não podem ter outro programa. ${ }^{36}$

A classificação proposta por Jorge Miranda constitui-se em normas constitucionais exeqüiveis por sí mesmas, normas preceptivas não excQüiveis por si mesmas e normas programáticas. A tripartição pretendida pelo referido autor é muito esclarecedora porQue ressalta a Qualidade única das normas programáticas, senão vejamos:

"Quer as normas programáticas Quer as normas preceptivas não exeQǘveis por si mesmas caracterizam-se pela relevância específica do tempo, por uma conexa auto limitação e pela necessidade de concretżação, e não só de regulamentação e legislativa. Separam-se, no entanto, por as normas preceptivas não exeQüiveis por si mesmas postularem apenas a intervenção do legislador, actualizando-as ou tornando-as efectivas, e as normas programáticas exigirem mais do que isso, exigirem não só a lei como providências administrativas e operações materiais. As normas não exeqüiveis por si mesmas preceptivas dependem apenas de factores jurídicos e de decisões políticas; as normas programáticas dependem ainda (e sobretudo) de factores econômicos e sociais. Daí um maior

${ }^{34}$ Da Silva, losé AJonso. op.cit. p. 126.

35 MEIRELLES TEIXEIRA, losé Horácio. Curso de Direito Constitucional. Rio de Janeiro: Forense, 1991, p. 324 .

36 MIRANDA, Pontes. Comentários à Constituição de 1967. Tomo I. São Paulo: RT, 1967, p. 129. 
grau de liberdade do legislador perante as normas programáticas do Que perante as normas preceptivas não exeQǘveis: estas deverão ser completadas pela lei nos prazos relativamente curtos delas decorrentes; já as normas programáticas somente terão de ser concretizadas Quando se verificarem os pressupostos de facto Que tal permitam, a apreciar pelo órgão legislativo. [... nas normas não exeqüiveis por si mesnias programáticas tem ainda de se dar uma terceira instância - a instância política, administrativa e material, única com virtualidade de modificar as situações e os circunstancialismos econômicos, sociais e culturais subjacentes à Constituição."(MIRANDA, J., 1996, p. 248 e 249)

Por sua vez, Celso Ribeiro Bastos tece críticas à polêmica tese da Constituição Dirigente, proposta por Joaquim José Gomes Canotitho, o Qual defendia o caráter vinculante e obrigatório das normas programáticas, o Que gerou a retirada destas normas da Constituiçâo de diversos países europeus. ${ }^{37}$ Assim, Celso Bastos sustenta a indispensabilidade da inclusão das normas programáticas na Constituição, ainda Que não gerem a legislação própria, propiciam um Quadro favorável para serem colocadas em prática. ${ }^{38}$

37 Segundo FERREIRA FILHO, Manoel Gonçalves: "Parece-me, todavia, necessário observar que a idéia de Constituição dirigente, além do viés ideológico, tem uma postura jurídica que pode ser vista como independente daquela opção 'programática'. O aspecto jurídico é a idéia de o Poder Constituinte vincular os Poderes estabelecidos de acordo com a Carta que estabelece ao desenvolvimento e concretizaçäo de płanos e programas que desenha. Ou seja, a idéia de que o Constituinte pode - talvez deva - comandar os govemos constitucionais a cumprir as normas programáticas Que prevê. É para isto que uma Constituição dirigente prevê instrumentos judiciais como a ação de inconstitucionalidade por omissão e congêneres. Esta idéia teria justificativa se, realmente, o Poder Constituinte fosse um Poder de natureza diferente, de força superior, da dos Poderes Constituídos. Entretanto, como todos sentem se não sabem, o Poder Constituinte é um Poder representativo. tanto quanto os Poderes constituídos. Assim, as superioridade é meramente forma, não sendo mais do que a dos poderés constitúídos; apenas sua função é anterior a estes e fundadora destes." Estado de Direito e Constituição. São Paulo: Saråva, 2004, p.68 e 69.

38 Conforme BASTOS, Celso Ribeiro: "A corrente marxista foi liderada na América Latina, Espanha e Portugal pelo Prof. loaquim José Gomes Canotilho. Em tese apresentada na Alernanha sobre Constituição Dirigente, demonstra ele Que o legislador está diante da Constituiçăo, da mesma forma Que o administrador está para a lei. Tem uma discricionariedade, porém não condizente com liberdade ampla e irrestrita. Sendo assim, se a Constituição determina algo, obrigatoriamente terá que agir desta forma, gozando apenas de certa margem de liberdade na escolha da forma na qual irá fazer. A grande inovaçăo desta tese é a submissăo do Poder Legislativo às diretrizes e aos programas fixados na Constituiçäo. Posteriormente, tomou-se a bandeira da intelectual esquerda dentro do Constitucionalismo, porque era a forma de vingar as teses marxistas. Foram implantadas as concepçôes programáticas e criado institutios como o mandato de injunção e a ação de inconstitucionalidade por omissão, vindo por atarefar ainda mais o Judiciário. A esquerda marxista, mediante a situação politica Que tinha sido ałterada na Europa, revisou a Constituição e expeliu as normas programáticas do seu texto. Tenho rebatido, juntamente com outros escritores, a tese de Canotilho, oue finalmente reposicionou-sc em torno do tema, retirando o caráter vinculante e obrigatório das normas programáticas. A conclusão mais acertada é a de se admitir a inclusão das normas programáticas na Constituiçăo. Elas são importantes mesmo Quando näo geram a tegislaçăo própria. Criam o clima favorável para serem postas em prática. Além do mais, tornam inconstitucionais certas medidas praticadas contra suas idéas. Se porventura tentar-se aprovar alguma lei cm sentido contrário ou revogar alguma Que dá sustentaçăo ao preceito maior. é perfeilanzente possivel alegar inconstilucionalidade." Normas Programáticas - Natureza e casos concretos. Revista da Procuradoria da Repúbíca n. 9: São Paulo, RT, 1996, p.35. 
Importa transcrever breve trecho do conceito de normas programáticas elaborado por Vezio Crisafulli, vejamos:

"Le norme costituzionałi programmatiche, si è visto, non regolano direttamente lê materie cui purê si referiscono, ma regolano propriamente l'attività statale in ordine a dette materie: hanno ad oggetto immediato comportamenti statali, e soltanto mediatamente e, per dir così, in secondo grado Quelle certe materie." (CRISAFULLI, 1947, p.75)

Partindo da origem histórica das normas programáticas, percebe-se Que estas normas visam atingir metas, as Quais consubstanciam-se nos chamados fins sociais do Estado, direitos e pretensões de sentido social, Que infiltraram-se nas Constituições modernas, assumindo a roupagem de preceitos constitucionais. ${ }^{39}$

Assim, a eficácia plena das normas programáticas dependem do seu desenvolvimento por lei ordinária, daí a eficácia limitada, a pual deve seguir as diretrizes estabelecidas constitucionalmente.

Devido a importância das normas programáticas no desenvolvimento social, cultural, de bem estar da população, econômico, saúde, entim, nos fins últimos do Estado, estas normas possuem um mecanismo jurídico de proteção. Esta proteção visa impossibilitar Que as normas programáticas sejam atingidas, mesmo indiretamente, assegurando Que estes comandos valores possam produzir eficácia plena.

Tem sentído primárío prescritivo, e nâo proibitivo, adQuirindo complementarmente, um duplo sentido proibitivo ou negativo. Proíbem a edição de normas legais contrárias e a prática de comportamentos Que tendam a impedir a produção de atos por elas impostos.

Esta eficácia secundária, por assim dizer, confere ao beneficiário direto ou indireto da norma programática, meios para assegurar futuramente a plena eficácia da norma constitucional, afastando tanto atos emanados do Poder Legislativo Quanto do Executivo Que sejam manifestamente contrários. Com efeito, estas normas mesmo Quando não geram a legislação própria, criam o clima favorável para serem postas em prática.

39 MEIRELleS TEIXEIRA, José Horácio. Curso de Direito Constitucional. Rio de janeiro: Forense, 1991. p.185. 
Nestes termos, as normas programáticas fixam critérios ou direções para o legislador ordinário nas matérias Que versam, gerando inconstitucionalidade material ${ }^{40}$, Quando haja afastamento desses critérios, conforme já exposto no capítulo 2.l. Sempre que uma lei ordinária ou ato normativo da Administração imponham obrigações, estabeleçam ônus, neguem benefícios, estabeleçam limitaçôes à atividade individual, contrariamente à princípios programáticos, nasce a possibilidade de suscitar a declaração de inconstitucionalidade. Podese, por assim dizer, Que a inconstitucionalidade material aqui tratada é uma das eficácias secundárias das normas programáticas.

Outro efeito secundário é a impossibilidade de revogação da norma infraconstitucional Que concretizou o comando constitucional. Pode-se dizer que esta eficácia gera uma verdadeira "blindagem constitucional" da norma ordinária, pois não pode pura e simplesmente ser revogada, retornando-se à situação anterior. Verifica-se Que a revogação da norma infraconstitucional, a Qual produz a eficácia primordial da norma programática, configura um retrocesso, daí o nome de cláusula do não retrocesso mencionado na doutrina. Somente através de emenda constitucional superveniente, a lei ordinária que efetiva o comando constitucional programático, pode ser revogada.

Por imperativo da democracia, o legislador tem a faculdade de modificar qualeuer regime jurídico, o que não tem é a faculdade de subtrair supervenientemente, de uma norma constitucional, a exeqüibilidade que esta tenha adquirido. Se a Constituição impõe ao Estado a realização de uma determinada tarefa, como a criação de uma instituição ou uma alteração na ordem jurídica, Quando ela for atendida passa a ter a proteção direta da Constituição. ${ }^{4 !}$

No Que tange a legislação ordinária anterior, Que confronte com disposição programática superveniente, Jorge Miranda afirma Que são inconstitucionais. Porém, somente a partir do momento Que seja possivel, diante da realidade constitucional, receber exeqüibilidade. ${ }^{42}$

Outra eficácia reflexa ou secundária da norma programática é a interpretação de outras normas, as Quais, sem elas, poderiam ter alcance diverso. Segundo Paulo Bonavides, é indispensável a análise histórico-teleológica de um texto constitucional, onde nenhum

to BONAVIDES, Paulo assim define controle de constitucionalidade material " $[$... é delicadíssimo em razăo do elevado teor de politicidade de que se reveste, pois incide sobre o conteúdo da norma. Desce ao fundo da lei, outorga a quem o exerce competência com que decidir sobre o teor e a matéria daregra jurídica, busca acomodá-la aos cânones da Constituiçăo, ao seu espírito, à sua filosolia, aos seus princípios políticos fundamentais. É controle criativo, substancialmente político. Sua caracterização se constitui no desespero dos publicistas que entendem reduzi-fo a uma feição puramente jurídica, feição inconciliável com a natureza do objeto de que ele se ocupa, que é o conteúdo da lei mesma, conteúdo fundado sobre valores, na medida em Que a Constituição faz da liberdade o seu fin $e$ fundamento primordial." Curso de Direito Constitucional. 14 a ed. São Paulo: Malheiros, 2004, p. 299.

4) MIRANDA, Jorge. Manual de Direito Constitucional. Tomo Il. Coimbra: Coimbra, 1996, p 25 I.

42 MIRANDA, lorge. op.cit. p. 252. 
constitucionalista pode afastar tal exercício interpretativo. Afirma que é o instrumento mais significativo de que dispõe a hermenêutica constitucional, sobretudo da norma programática. ${ }^{43}$

Todas as normas jurídicas estão sujeitas ao inevitável influxo do desenvolvimento histórico, porém a programática é a que melhor reflete o conteúdo axiológico Que circundam a Sociedade. Por outro lado, reflete seu frágil e impreciso caráter técnico-jurídico.

Entende-se por elemento histórico, aquele no qual é traçado toda história da proposição legislativa. Procura-se a ambiência Que se originou a lei, procura trazer à luz os intervenientes fatores políticos, econômicos e sociais. Por sua vez, o elemento teleológico busca o fim especial da norma, Quando o intérprete mergulha profundamente na alma do legislador. ${ }^{44}$

Com posição similar, Luís Roberto Barroso discorre Que as normas programáticas contêm disposições indicadoras de valores a serem preservados e de fins sociais a serem alcançados. Tem por característica a não especificação de QualQuer conduta a ser obrigatoriamente adotada pelo Poder Público, apenas aponta linhas diretoras. Explicitam fins, sem indicar os meios, investindo os jurisdicionados numa posição jurídica menos consistente, do Que as normas de condutas típicas. Com efeito, não conferem direito subjetivo em sua versão positiva de exigibilidade de determinada prestação. Todavia, fazem nascer um direito subjetivo negativo de exigir do Poder Público que se abstenha de praticar atos Que contravenham os seus ditames. Por via de conseqüência, as potencialidades que oferecem são distintas e o intérprete e aplicador da norma tem de ser atento a isso. ${ }^{45}$

Verifica-se que os países que adotam normas constitucionais programáticas em suas constituições, devem ter consciência e maturidade para visualizar o alcance pretendido por estas normas. Os valores garantidos devem ser buscados com a comunhão de forças políticas de toda a sociedade, entendida como um grupo em busca de um fim comum, e não cada um individualmente. Ao ler a Constituição cada cidadão não deve visualizar o seu próprio reflexo, mas ter a consciência Que está integrado numa comunidade.

Conforme já exposto no capítulo 1.1 , estas normas refletem a evolução do Estado Liberal para o Estado Social. Esta vitória deu-se em razão do predomínio como valor supremo a igualdade, o Que posteriormente foi traduzida numa ponderação de valores, tendo como fim último o bem estar de todos. Percebe-se Que a inserção de normas constitucionais programáticas no ordenamento jurídico é o primeiro passo para conQuistar o bem comum. Sendo apenas o início de uma caminhada de homens livres, pois uma Constituição não é, nem pode ser, a pré-moldagem da sociedade civil, mas sim o enunciado de modelos jurídicos abertos.

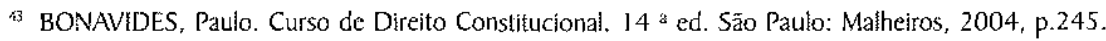

4 BONAVIDES, Paulo. op.cit, p.446.

45 BARROSO, Luís Roberto. Interpretação e Aplicação da Constituição. São Paulo: Afiliada, 1996, p.104. 
A Constituição deve proporcionar meios e modos para superar inevitáveis conflitos econômicos, políticos ou culturais através do livre jogo dos interesses e das idéias, conforme as opções soberanas do eleitorado. ${ }^{46} \mathrm{Na}$ democracia social cabe ao legislativo, cujo poder foi outorgado pelo povo, traduzir a vontade política da populaçāo, pois numa democracia é o poder habilitado para tanto. Assim, a Constituição não relaciona um rol de soluções, por outro lado, é a garantia Que, com base na experiência social, estas sejam livremente alcançadas. É impossivel um comando normativo constitucional antecipar entendimentos e negociações a serem futuramente concluídos pelos indivíduos interessados.

A Constituição é um meio, não um rol de soluções previamente estabelecidas, pela Assembléia Constituinte, para todos os problemas da nação. A solução vem da abertura $\mathrm{e}$ diretrizes das normas programáticas, nas matérias que lhe dizem respeito. Sem considerar fatores históricos, políticos, econômicos e sociais, Que marcam o povo, a eficácia destas normas nunca será atingida efetivamente. ${ }^{47}$ A eficácia plena das normas programáticas será alcançada gradualmente no Brasil cuando a Política e o Direito caminharem juntos, respeitando mutuamente suas atribuições, tendo como fim último a sociedade.

\section{CONCLUSÄO}

Constatou-se, ao longo do presente trabalho, Que a classificação das normas constitucionais Quanto à eficácia é um dos temas, em direito constitucional, Que mais suscitam opiniōes antagônicas.

Num primeiro momento, buscou-se a raiz histórica das normas programáticas, onde ficou evidenciado o seu importante papel na mutação do Estado Liberal para o Estado Social. No século passado, mais precisamente a partir do primeiro pós-guerra, direitos sociais relativos ao trabalho, educação, cultura, previdência, saúde, desconhecidos do constitucionalismo clássico, ganharam espaço nas constituições. A constituição de Weimar foi o marco do constitucionalismo social, refletindo na face moderna das constituições, Que é sem dúvida alguma, a das normas programáticas.

As normas programáticas foram inseridas nas constituições num momento onde o valor liberdade foi relativizado pelo valor igualdade, através da intervenção do Estado buscando conferir direitos sociais aos cidadăos. Estas normas constitucionais năo estipulam rigidamente a forma e o momento como o Estado deve agir para garantir o acesso a direitos sociais, somente prevêem parâmetros que o legislador deve observar. Conferem ao legislador ordinário a tarefa de conceder eficácia plena a norma programática, pela via democrática do amplo debate de ideologias. Estas normas não representam soluções prontas, mas instrumentos

\footnotetext{
4 REALE, Miguel.Liberdade e Dernocracia. São Pauło: Saraiva, 1987, p. 17.

47 FERREIRA FILHO, Manoel Gonçalves. O Poder Constituinte. 2a ed. Săo Paulo: Saraiva, 1985, p.158.
} 
para homens livres decidirem sobre o seu futuro, valorizando a liberdade de escolha política do povo. Assim, a consciência jurídica do aplicador do direito é de suma importância para evitar a usurpação de poderes, devido as normas programáticas exigerem uma instância política, administrativa e material, única capaz de modificar as situações e circunstâncias econômicas, sociais e culturais que transcendem ao texto constitucional, conforme o magistério do professor forge Miranda. Esta característica confere um maior grau de liberdade do legislador, pois as normas programáticas serão concretizadas Quando se verificarem presentes os pressupostos de fato, Que permitam serem apreciadas pelo Poder Legislativo.

Outro tema que está longe de encontrar consenso na doutrina é se as normas programáticas produzem direitos subjetivos. Alguns doutrinadores sustentam a possibilidade do particular invocá-las visando embasar dissídio que o favoreça, outros discordam afirmando Que estas normas não produzem situações jurídicas subjetivas positivas. Porém, há um certo consenso na produção de situaçōes jurídicas subjetivas no seu aspecto negativo, ou seja, o particular pode insurgir-se contra ato administrativo ou lei manifestamente contrários a disposições programáticas.

Por último, a eficácia plena das normas programáticas será alcançada somente com a edição da correspondente legislação ordinária, razão pela Qual é denominada de eficácia limitada, non-self-executing, non-self-enforcing, não auto aplicáveis e não bastantes em si. O legislador infra constitucional não pode distanciar-se dos princípios programáticos, pois estabelecem as diretrizes para atingir os fins últimos da norma. Devido ao relevante papel destas normas no desenvolvimento da nação, há meios jurídicos para sua proteção, denominados de eficácia secundária ou reflexa da norma programática.

\section{REFERÊNCIAS BIBLIOGRÁFICAS}

ATALIBA, Geraldo. República e Constituição. $2^{\mathrm{a}}$ ed. São Paulo: Malheiros, 2001.

BONAVIDES, Paulo. Do Estado Libera! ao Estado Social. $7^{a}$ ed. São Paulo: Malheiros, 2004.

. Curso de Direito Constitucional. $14^{a}$ ed. São Paulo: Malheiros, 2004.

BARROSO, Luís Roberto. Interpretação e Aplicação da Constituição. São Paulo: Afiliada, 1996.

CRISAFULLI, Vezio. La Costituzione e le sue disposizioni di principio. Milano: A. Giuffre, 1947.

DA SILVA, José Afonso. Aplicabilidade das Normas Constitucionais. São Paulo: Malheiros, 1998.

. Curso de Direito Constitucional Positivo. São Paulo: Malheiros, 1999. 
FERREIRA FILHO, Manoel Gonçalves. O Poder Constituinte. $2^{\text {a }}$ ed. São Paulo: Saraiva, 1985.

____. Estado de Direito e Constituição. São Paulo: Saraiva, 2004.

MEIRELLES TEIXEIRA, José Horácio. Curso de Direito Constitucional. Rjo de Janeiro: Forense, 1991.

MIRANDA, Jorge. Manual de Direito Constitucional. Tomo II. Coimbra: Coimbra, 1996.

Teoria do Estado e da Constituição. Rio de Janeiro: Forense, 2002.

MIRANDA, Pontes. Comentários à Constituição de 1967. Tomo I. São Paulo: RT, 1967.

REALE, Miguel. Liberdade e Democracia. São Paulo: Saraiva, 1987.

SOUZA JUNIOR, Cezar Saldanha. A Supremacia do Direito no Estado Democrático e seus modelos básicos. Porto Alegre, 2002. 